\title{
Factors that Influence the Teaching Skills of SMK Business and Management Teachers in Padang
}

\author{
Henti Teja Utami ${ }^{1}$, Syamwil ${ }^{*}$ \\ 1 Universitas Negeri padang, Padang, Indonesia, $\square$ tejautami.henti@yahoo.com \\ 2Universitas Negeri padang, Padang, Indonesia, $\square$ syamwil@fe.unp.ac.id
}

\begin{abstract}
This study aims to reveal: 1) Factors in the teaching skills of Vocational Business and Management Vocational Schools in Padang City, 2) the most dominant factors in the teaching skills of Vocational Business and Management teachers in Padang City. This research is a survey research that is intended to provide an explanation or referred to as exploratory research that is to see the dominant factors in teachers skills teaching in Business and Management Vocational Schools in Padang City. The total population is 328 teachers, the sampling technique is Proposal Random Sampling . The sample of this study is 180 teachers. The data analysis technique used is factor analysis. The results of the study are: 1) Final results of the Kaiser Meyer Olkin (KMO) shows the number 0.704 which is in the Good category. This means that the value of Kaiser Meyer Olkin (KMO) can explain that the variables of the teaching skills of teachers of Business and Management Vocational Schools in Padang City are good and sufficient for further analysis. 2) eight most dominant variables were formed in the teaching skills of SMK Business and Management teachers in Padang City are: (1) Communication, (2) Guiding Students , (3) Class Management, (4)Learning Methods, (5) Personal, ( 6) Varies, (7) Creative Thinking (8) Asking questions.
\end{abstract}

Keywords : teaching skills, teachers skills

\section{Introduction}

Education is seen as the right way to form quality human beings to support the achievement of national development goals. Through education, people get knowledge, skills, values and attitudes so they can think more systematically, traditionally, and critically about the problems they face. Quality of education berk can be realized through the learning process, while the success of someone $\mathrm{d}$ natural learning process is determined by many factors, among other factors and factors indiv idu educators. (Mulyasa., 2015; \& Slameto ., 2010; \& Lankveld 2017), stated The success of learning is the achievement of the process of changing student behavior as a result of teacher interaction with students in the learning process. therefore the success of the teacher in the learning process is the most important responsibility to support the achievement of learning goals . teacher must have competencies that have been set by the standard curriculum to educate students to provide a good learning outcomes. Teacher competency is a abilities possessed by a teacher include aspects of knowledge, skills, thought processes, self-adjustments, attitudes and values adopted in carrying out profession as teacher and teacher able to think and act consistently continuously in accordance with their competence (Forster \& Quarcoo., 2018; and Lai et al., 2018.,) The results of preliminary observations showed that the School Teachers who were Vocational Education in Padang 3 found that the learning process was good but there were obstacles in teaching teachers, namely explaining focused teacher materials with several students active in class situations so that students who were passive only listened without being actively involved in learning process. However, in reality the increase in professional capacity is not easy for teachers because of the teacher's competency standards that must be possessed relating to the objectives and content of learning that can support student development and position in knowledge that can be well prepared so that the learning process is created effectively. So the purpose of this study is to find out the process of applying teacher 
teaching skills in optimizing the learning outcomes of Vocational and Business Vocational Students in Padang City and the most dominant factors in the teaching skills of Vocational Business and Management teachers in Padang City . (Hotaman.,2010; \& Hashim et al.,2015; \& Neghavati.,2016) stating the teacher's teaching skills is teacher teaching skills such as planning the teaching process, offering variety, using effective instruction time, creating a participatory learning environment, monitoring student progress and ensuring student self-control . (Usman.,2017; \& Saud.,2016; \& Imron.,2016) states that there are 9 teacher teaching skills, namely opening and closing skills, explaining skills, asking skills, strengthening skills, small group guiding skills, classroom management skills, using learning media, variations in skills, individual and small group teaching skills.

(Lee \& Cross Francis.,2018; \& Ngang et al.,2015) stated that the skill of opening and closing lessons is an effort made by the teacher in learning activities to create preconditions for students so that mental and attention are centered on the learning experience presented so that it will easily reach the expected competencies and provide a comprehensive picture of what students have learned from previous experience to see the level of success of students. The skills of opening and closing in reality teachers who are able to provide motivation and plan well in the learning process will give students enthusiasm in participating in learning activities. Sari and Jusar (2018) stated that teachers who have the skills to open lessons can help students prepare themselves so that they can imagine the lessons they will learn from the beginning, raise students' interest and attention to what they will learn in teaching and learning activities, helping students to know the relationship between experiences that have been mastered by new things that will be learned or unknown, and know the level of success of students in learning subject matter .

Life Skills me njelaskan is to $\mathrm{m}$ am pared with the teacher in presenting information orally organized systematically to show their relationship to one another, such as between and as a result, the definition of premises n samples or the unknown (Darmawati 2017., \& Bietenbeck., 2014 ). Well-planned information delivery by the teacher is one of the most important aspects of the teacher's activities in interacting with students in the classroom as students easily understand the material explained by the teacher. As explained by Abidin et al., (2018) that the explanatory skills that must be possessed by the teacher aim to guide students to understand the material being studied, involve students to think by solving problems that arise in the learning process. (Shakibaei \& Golaiji.,2012; \& Akkaya et al., 2012) stating questioning skills is the skill of a teacher in giving questions in the form of verbal sayings directed at students to ask for answers so that they are capable of critical thinking and rational reasoning skills. The important thing is that students ask also to develop students' thinking patterns as opportunities for students to show their attitudes, skills and understanding of the substance of learning given, build an attitude of openness to give and receive opinions or ideas, build a sense of responsibility for students to ask questions, familiarize students with spontaneous and prompt thinking, and be swift in responding to problems, and to arouse the skills of students in speaking. Asril (2010) explain that states that students' questioning skills and learning skills show a positive relationship. Positive relationship interpreted the higher the value of the questioning skills, the learning outcomes will also increase. (Van Lankveld et al.,2017; \& Stillman et al.,2017; \& Karabay et al.,2018) Expressing skills to provide reinforcement is a skill whose direction is to give encouragement, responses, or gifts to students so that in attending the lesson students feel respected and cared for . teacher skills provide reinforcement that will have an impact on a child's ability to understand, regulate, and utilize emotions to increase self-awareness, make optimal decisions, set goals, and connect well with others greatly impact on the results and abilities of his life. According to Waes et al., (2017) , reinforcement skills have a positive influence on students on the learning process and aim to increase students' attention to learning, stimulate and increase interest in learning, improve learning activities and foster productive student behavior.

Zheng, Yim et al., (2017) states that learning media is a learning tool that is used as an intermediary who can appreciate students' thinking in the learning process to achieve learning goals effectively and 
efficiently. teacher's skills in designing a learning media that is suitable with learning objectives, learning material, learning methods and the ability to attract students to overcome the limitations of space, time and the senses, facilitate the course of the learning process . Mulyani and Johar (2001), state the influence of the learning process supported by using learning media will provide benefits in facilitating students to understand the material conveyed by the teacher and attract students' attention in learning. (Ngang et al.,2015; \& Bennett et al.,2004), stating that small group discussion skills have been highly recommended as approaches in learning partly emerge from more general movements towards student-centered learning, and partly as a means of drawing recommendations from constructivist research, which is considered very important to give students the opportunity to reflect on their own ideas in scientific phenomena.

Kennedy (2017) states that the skill of managing classes is a teacher's skill to create and maintain optimal learning conditions and return them to optimal conditions in the event of a disruption, either by disciplining or conducting remedial activities. To promote student discipline strict teacher attitude is needed. The attitude of the teacher is synonymous with friendliness and warmth towards students but also must remain firm in matters relating to student discipline both in terms of classroom learning and school rules. Ways (2013) states that in an effort to strengthen student learning discipline it is necessary to have classroom management in the learning process carried out by the teacher which aims to create an effective and efficient learning process for students. Wighus \& Bjørk, (2018) states that the skill of holding variations is held because the boredom factor caused by the presentation of monotonous learning activities will result in students' attention, motivation, and interest in learning, teacher, and school decreasing, so diversity is needed in the study. learning activities. Yamin (2013) the skill of holding variations is held because the boredom factor caused by the presentation of monotonous learning activities will result in students' attention, motivation, and interest in learning, teachers, and schools decreasing, so diversity is needed in presenting learning activities . (Dilekli \& Tezci.,2016; \& Burke 2011) states the teaching skills of small groups and individuals are interpreted as the actions of teachers in the context of teaching and learning which only serves 3-8 students for small groups, and only one for individuals. The teacher must be skilled at planning learning according to the program and needs of students, and able to carry out the plan. teacher role as organizer, personally approached skills, skills to guide and facilitate learning so that students can truly learn and learning objectives can be achieved, the teacher must be skilled in forming students to easily learn and not suffered a broken spirit. Stocker ( 2014) states that the teaching of small groups and individuals allows teachers to pay attention to each student and the occurrence of a more intimate relationship between teacher and student and between students and students and can meet student needs optimally.

This study discusses the teaching skills factors of vocational teachers in the city of Padang to get the results of the importance of the role of teachers in the achievement of students in the learning process. Teachers who have competence in teaching are able to apply the most dominant factors in teaching skills. The aim of this study was to find: The process of applying teacher teaching skills in optimizing the learning outcomes of Vocational and Management Vocational Students in Padang City, if the teaching skills of vocational business and management teachers in Padang City, is the most dominant actor in the teaching skills of vocational business and management teachers in Padang City

\section{Methods}

This research is a survey research that is intended to provide an explanation or referred to as exploratory research. This research was conducted at Vocational Schools in the City of Padang. The number of pop pop 328 teachers who teach vocational schools in Padang City. The sampling technique in this study was proportional random sampling as many as 180 teachers who teach Accounting expertise. Data collection techniques in this study were using questionnaires and had 35 indicators after testing 
found 32 indicators used in the research process. The valid item for the instrument is to see the value of Corrected Item Total Corelation. For $\mathrm{n}=30, \mathrm{r}>0.3640$, so that obtained from 79 items after validation obtained 74 item numbers declared valid and 5 item numbers declared invalid. To determine a reliable instrument is to look Croncbach Alpha value close to 1, then this means that respondents tend to be the same even if given at different respondents and reliable if the value Croncbach Alpha $>0,5$. It can be concluded from 9 variables that the criteria for reliability are sufficient ( $0.60-0.80)$ and High $(0.80-1.00)$. Data were analyzed using factor analysis using the Statistical Package for the analysis tool The Social Science (SPSS).

\section{Results and Discussion}

Table 1 Distribution of Teaching Skills

\begin{tabular}{lccc}
\hline \multicolumn{1}{c}{ Variable } & Mean & TCR & category \\
\hline skills to open and close lessons & 3.83 & 76.76 & Well \\
\hline explanatory skills & 3.81 & 76.20 & Well \\
\hline questioning skills & 3.59 & 71.84 & Well \\
\hline skills provide reinforcement & 3.55 & 71.03 & Well \\
\hline media use skills & 3.62 & 72.44 & Well \\
\hline Life Skills initiate discussion & 3.72 & 74.57 & Well \\
\hline class management skills & 3.38 & 67.68 & Well \\
\hline variation skills & 3.76 & 75.22 & Well \\
\hline individual and small group teaching skills & 3.37 & 67.52 & Well \\
\hline Total & 32.63 & 653.26 & \\
\hline Average & 3.62 & 72.58 & Well \\
\hline
\end{tabular}

Table 1 explain from the data that there is the highest level of achievement of the highest respondents found in teaching skills and closing lessons that is equal to $76,76 \%$ with the Good category, this shows that the teacher in the learning process is able to carry out evaluations to students to see students' understanding of material has delivered. While the lowest level of achievement of the lowest respondents is in individual and small group teaching skills, which is equal to $67.52 \%$ with the Good category. This shows that the teacher has reviewed the material for discussion given to students but is still lacking in how to guide students in giving opinions. It can be concluded that the average Respondent Achievement Rate (TCR) is $72.58 \%$ with an average of 3.62 so it can be concluded that the level of respondent's answer criteria for teaching skills of vocational teachers in Padang City is good and dominated by opening and closing lessons before implementing the learning process the teacher seems to have been prepared to start planning the lesson plan as kegiata $\mathrm{n}$ introduction, core and closing.

Table 2 KMO and Bartlett's Test

\begin{tabular}{|c|c|}
\hline Kaiser-Meyer-Olkin Measure of Sampling Adequacy & .704 \\
\hline Bartlett's Test of Sphericity Approx.Chi-square & 2152.604 \\
\hline Df. & 703 \\
\hline Sig & .000 \\
\hline
\end{tabular}

Table 2 explains the value of Kaiser Meyer Olkin (KMO) measure of Sampling adequacy (M SA) obtained at 0.704 can explain that the results of factor analysis are included in the satisfying category. Likewise Barlety value "s Test Of Sphericity amounted to 2152.604 with a significance value of 0,000 which explains that the most dominant factor in teaching skills of vocational teachers in Padang City can be categorized 
as good. Based on the results of factor analysis, there are 32 indicators that meet the requirements for further analysis and group into 8 factors with new names, namely (1) Communicating , (2) Guiding Students , (3) Class Management , (4) Using Methods, (5) Personal, (6) Varied, (7) Creative Thinking (8) Asking questions.

Table 3 Factors Formed

\begin{tabular}{|c|c|c|c|}
\hline No. & Variable & Eigenvalue & $\begin{array}{l}\text { Loding } \\
\text { Factor }\end{array}$ \\
\hline 1 & $\begin{array}{l}\text { Explanation related to the material provided by the } \\
\text { teacher }\end{array}$ & \multirow{5}{*}{ Communicate } & 0.925 \\
\hline 2 & $\begin{array}{l}\text { Explanation must be in accordance with student } \\
\text { characteristics }\end{array}$ & & 0.924 \\
\hline 3 & Concrete explanation & & 0.917 \\
\hline 4 & Explanation relevant to learning objectives & & 0.924 \\
\hline 5 & Plan the presentation of an explanation & & 0,877 \\
\hline 6 & Obtain a problem or proposal & \multirow{9}{*}{$\begin{array}{l}\text { Guide } \\
\text { The Self }\end{array}$} & 0.876 \\
\hline 7 & Focus the topic of discussion & & 0.742 \\
\hline 8 & Guiding and facilitating learning & & 0.731 \\
\hline 90 & Maintenance of optimal learning conditions & & 0.702 \\
\hline 10 & Analyze student views or opinions & & 0.695 \\
\hline 11 & Opportunity to participate & & 0.607 \\
\hline 12 & Use of learning technology & & 0.602 \\
\hline 13 & Closing the discussion & & 0.492 \\
\hline 14 & Strengthening is given in a variative manner & & 0.475 \\
\hline 15 & Revisit core mastery of the lesson & \multirow{5}{*}{ Class Management } & 0.876 \\
\hline 16 & Attract students' attention & & 0.822 \\
\hline 17 & Motivate students & & 0.817 \\
\hline 18 & Give a reference & & 0.822 \\
\hline 19 & Evaluate & & 0.774 \\
\hline 20 & Plan and conduct learning activities & \multirow{3}{*}{ Use Method } & 0.858 \\
\hline 21 & Organize & & 0.833 \\
\hline 22 & Hold a personal approach & & 0.744 \\
\hline 23 & Develop self discipline & \multirow[b]{3}{*}{ Personal } & 0.758 \\
\hline 24 & Flexibility & & 0.723 \\
\hline 25 & Warmth and enthusiasm & & 0.701 \\
\hline 26 & Variation with teaching style & \multirow[b]{3}{*}{ Varies } & 0.858 \\
\hline 27 & $\begin{array}{l}\text { Variation of patterns of interaction with teaching } \\
\text { styles }\end{array}$ & & 0.848 \\
\hline 28 & Variation in the use of learning media & & 0.688 \\
\hline 29 & Ease of students to understand the concept & \multirow[b]{2}{*}{ Creative Thinking } & 0.831 \\
\hline 30 & Appropriate & & 0.761 \\
\hline 31 & Basic questions & \multirow[b]{2}{*}{ Asking } & 0.925 \\
\hline 32 & Further questions & & 0.859 \\
\hline
\end{tabular}


Table 4 Total Variance Explained

\begin{tabular}{|c|c|c|c|c|c|c|}
\hline \multirow{2}{*}{ Component } & \multicolumn{3}{|c|}{ Initial Eigenvalues } & \multicolumn{3}{|c|}{$\begin{array}{l}\text { Extraction Sums of Squared } \\
\text { Loadings }\end{array}$} \\
\hline & Total & $\begin{array}{c}\% \text { of } \\
\text { Variance }\end{array}$ & Cumulative\% & Total & $\begin{array}{c}\% \text { of } \\
\text { Variance }\end{array}$ & Cumulative $\%$ \\
\hline 1 & 8093 & 23.124 & 23.124 & 8093 & 23.124 & 23.124 \\
\hline 2 & 6,126 & 17,501 & 40,625 & 6,126 & 17,501 & 40,625 \\
\hline 3 & 4,666 & 13,331 & 53,956 & 4,666 & 13,331 & 53,956 \\
\hline 4 & 3,049 & 8.711 & 62,667 & 3,049 & 8.711 & 62,667 \\
\hline 5 & 1,583 & 4,522 & 67,189 & 1,583 & 4,522 & 67,189 \\
\hline 6 & 1,376 & 3,931 & 71,120 & 1,376 & 3,931 & 71,120 \\
\hline 7 & 1,244 & 3,554 & 74,674 & 1,244 & 3,554 & 74,674 \\
\hline 8 & 1,036 & 2,960 & 77,634 & 1,036 & 2,960 & 77,634 \\
\hline
\end{tabular}

Source: 2019 Primary Data (Processed)

Based on the results of the initial observations, researchers used 9 teacher teaching skills variables so that the most dominant factors in the teaching skills of Vocational Business and Management Vocational Schools in Padang City consisted of 32 factors, but after factor analysis, the teaching skills of Vocational and Management Vocational teachers consists of 8 factors, namely (1) Communication Skills, (2) Student Guiding Skills, (3) Technology Management Skills, (4) Class Management Skills, (5) Method Using Skills, (5) Personal Skills, (6) Varying Skills, (7) creative thinking skills, (8) questioning skills. According to Hsia., Et al., (2016), teacher teaching skills are the teacher's ability to develop strategies that can help students reflect on their performance by giving them visualization of teacher feedback to students of various skills in personal teacher performance, learning motivation, self-efficacy, communication skills, peer truth assessment, and the behavior of technology-based online learning skills. Meanwhile, according to Zainuddin (2018), stated that the current progress in learning integrates technology in education using the learning process models, methods and strategies. Teaching strategies are part of teacher teaching skills in which students can understand the content of teaching in the classroom as given a learning video that can inspire students to learn. Activities in the classroom are then focused more on promoting students' high-level thinking skills or knowledge construction, such as small group discussions, dialogue, presentations, and receiving and giving conversations. In the case of professionals, a teacher must master teaching skills in terms of: opening and closing lessons, asking questions, giving reinforcement, and making variations in teaching. Wijaya (2016: 25-30) states that the professional abilities that teachers must possess in the teaching and learning process are: (1) mastering the material, (2) managing the teaching and learning program, (3) managing the class, (4) using source media, ( 5) mastering educational foundations, (6) managing teaching and learning interactions, (7) assessing student achievement for teaching purposes, (8) recognizing the functions and programs of guidance and counseling services, (9) getting to know and administering school administration, and (10) understand the principles and interpret the results of educational research for teaching needs. These competencies aim to: (1) improve the skills of asking new teachers so that the teaching and learning process does not take place monotonously and not only one-way interactions occur, (2) improve the skills of new teachers in classroom management so that the teaching and learning process can take place safely and orderly (3) improving the skills of new teachers in conducting teaching variations, especially variations in media use, variations in views and attention, and variations in the use of teaching methods, and (4) improving the skills of new teachers in explaining the material being taught. So that the naming of factors is formed 8 
factors which will be described as follows: Communication skill factor with Eigenvalues 8,602. Giving names in accordance with the factors formed is (1) A concrete explanation, (2) Explanation relevant to the purpose of learning, (3) Planning and conducting learning activities, (4) Explanation must match the characteristics of students, (5) Explanation related to the material given by the previous teacher. Based on the SKL (Graduates' Competency Standards) and SI (Content Standards) in the 2013 curriculum revealed improvement and balance between physical skills (hardskills) and mental skills (soft skills) to improve communication skills to improve the efficiency and effectiveness of learning. Hofmeyer et al., (2017), states that communication skills are the ability of teachers to adapt a conducive learning climate from the interaction of teachers and students in the learning process so that there is reciprocity.

The guiding factor of students with Eigenvalues 4.190. Giving names according to the factors formed is (1) focusing the topic of discussion, (2) guiding and facilitating learning, (3) maintaining optimal learning conditions, (4) Analyzing student views or opinions, (5) Opportunity to participate, (6) The use of learning technology, (7) Closing the discussion, (8) Variation given strengthened. Lewis, Ludwig, Nagel, \& Ames, (2019) , states that students' guiding skills are the ability of a teacher who is able to understand the conditions of students in the learning process and analyze the development of students about the material that has been studied so that they get maximum results. According to Suryosubroto (2002) there are teachers who use guided discovery methods, Guided discovery is a learning method that directs students to activities that can develop science process skills in which students are guided to find and investigate themselves about a science concept so that knowledge and skills are owned by students is not the result of remembering a set of facts but the results of their own findings.

Class Management factor with Eigenvalues 3,271. Giving names according to the factors formed is (1) reviewing the mastery of the core lessons, (2) attracting the attention of students, (3) motivating students, (4) giving references, (5) evaluating. Horng, Hsu, \& Tsai (2019), states that class management skills are a desire to cooperate with others cooperatively and become part of a group. Not working separately or competing with each other with a number of students interacting with one another so that everyone can communicate with all members directly in the learning process.

The factor uses a method with the value Eigenvalues 2.365. Giving names in accordance with the factors formed is (1) planning and carrying out learning activities, (2) organizing, (3) holding an interview personally. Learning conducted by teachers in Indonesia is generally still teacher-centered. This is caused by insufficient understanding and learning paradigms that are not yet in accordance with the actions that should be taken. Research shows that differences in learning paradigms have an impact on student learning outcomes. Efforts to improve the quality of learning are also carried out by the government by implementing a number of rules, for example Permenpan No. 16 of 2009 concerning teacher functional positions and credit numbers, one of which teachers must choose the best problem solving method that can be used as part of learning. (Isa, 2010; \& Wina Senjaya., 2008). Declaring learning methods can be interpreted as a method used to implement plans that have been prepared in the form of real and practical activities to achieve learning goals.

Personal factor with the value of Eigenvalues 2.143. Giving names in accordance with the factors formed is (1) Developing self-discipline, (2) flexibility, (3) warmth and enthusiasm. 2013 Curriculum in Government Regulation Number 19 of 2005 concerning National Education Standards, namely the learning process in educational units is held interactively, inspiring, fun, challenging, motivating students to actively participate, and providing sufficient space for initiative, creativity, and independence in accordance with talents, interests, and physical and psychological development of students. In line with the opinion of Cheng \& Xie., (2018), it states the importance of investigating the relationship between teacher personal skills, personal characteristics that provide important understanding of designing teacher learning programs in a way that is more responsive to the needs of students. personal skills formulate standards for professional teachers related to effective teachers, teachers must know and 
understand in depth the material they teach and can explain it to students flexibly and be able to understand the characteristics of students in effective learning processes.

factors vary with the value of Eigenvalues 1,795. Giving names according to the factors formed, namely: (1) variations with teaching styles, (2) variations in patterns of interaction with teaching styles, (3) variations in the use of instructional media. Djamarah (in Sutrisno 2007: 28) says that varied methods are learning methods which in the teaching and learning process include variations in teaching styles, variations in using media and teaching materials, as well as variations in interaction between teacher and students. in the implementation the teacher has done 7 types of teaching styles according to Marno and Idris, namely (1) variations in the teacher's voice, (2) expression and motion variations, (3) changes in position, (4) silence or pause, (5) concentration, (6) concentration of attention, (7) contact view. Another variation made by the teacher is using a variety of media besides the use of audio visual media as the main media, the teacher also uses other media in the form of sheet scores. Another important variation is the variation in interaction patterns. The teacher uses more than one variety of interaction patterns, one of which is demonstration and question and answer. In line with the opinion of Cetindamar., Et al., (2016), states that managing technology as a discipline and potential challenges that arise in the learning process in the framework of innovation, operations, and strategies. Then, developing the potential impact of challenges on a long-term perspective provides an opportunity for professional educators the opportunity to consider existing knowledge and skills bases so that they can prepare themselves for the challenges they will face in the future.

Creative thinking factor with Eigenvalues value 1,252. Giving names in accordance with the factors formed is (1) Ease of students to understand the concept, (2) appropriate. In planning problem solving not varied strategies or those that encourage creative thinking skills to find answers to problems. Paying attention to the root of the problem, it is necessary to think about ways to overcome it. Especially in the 2004 curriculum (2003) mentioning the purpose of mathematics learning which focuses on practicing thinking and reasoning, developing creative activities, developing the ability to solve problems and communicate ideas. Efforts can be made in terms of material, learning processes, improvement and support of infrastructure, improving the ability of teachers to teach through upgrading or training, reducing or distributing materials into simpler parts (simplifying material content in the curriculum) or improving input quality ( students) at school. The approach to overcoming this problem, researchers put more emphasis on the learning process, because the process is the professional duty and responsibility of everyday teachers and will have an impact on the tasks in the next class. When referring to the identification of the causes of these weaknesses, the learning process requires a way that encourages students to understand the problem, increases students' creative thinking skills in preparing completion plans and engages students actively in finding their own problem solving, and encourages studentteacher learning only as a facilitator.

The factor asks with the value Eigenvalues 1,033. Giving names according to the factors formed is (1) asking basic (2) asking further questions. Questions can be classified according to their form and based on the content or content. Questions based on their form can be divided into convergent and divergent questions. While questions based on content or contents are based on Bloom's taxonomy (Ragawanti, 2006). Omar (2009) in his research entitled Teacher's Questioning Techniques and Their Potential in Heightening Pupils' Inquiry states that a good question is a high-level cognitive question because it can increase the level of thinking of students. The same thing was also stated by Shen and Yodkhumle (2006) who stated that to improve students' critical thinking skills, the types of questions that must be asked in the learning process are high-level cognitive questions. In addition to the types of questions, the technique of asking the teacher to ask questions is an important aspect to consider. The purpose of using effective questioning techniques is to increase student participation in the learning process. There are several questioning techniques that need to be considered by the teacher in asking questions such as the use of clear questions, giving waiting time, distributing questions, giving responses to student answers, 
and eliminating habits that disrupt the discussion process (Heyworth, 1987; Ragawanti, 2006; Shiying, 2011 ) The ability to ask a good teacher can be observed from the types of questions asked and the techniques of asking the teacher effectively. Good questions are questions that can improve students' thinking skills, namely high-level cognitive questions. While the effective teacher questioning technique can be observed from the use of clear questions, giving sufficient waiting time, evenly distributing questions, giving responses to student answers, and eliminating habits that disrupt the discussion process.

\section{Conclusion}

The results of the discussion of the factors of teacher teaching skills have 9 variables and found that there are 8 newest factors that are most dominant in teaching skills including: Communicating , (2) Guiding Students , (3) Class Management, (4) Using Methods , (5) Personal, ( 6) Varies, (7) Creative Thinking (8) Asking questions. The learning process activities that take place the interaction between students and teachers become the main point in the success of learning objectives and therefore the teaching skills of teachers are very important in improving student learning outcomes. So that it will be the most dominant factor in the application of teacher teaching skills that can be done with the learning process activities. Teacher teaching skills have several items that underlie teachers to become teachers who are competent such as professional, pedagogical, social and personality competencies in implementing effective learning.

\section{References}

Akkaya, N., \& Demirel, MV (2012). Teacher Candidates' Use of Questioning Skills in During-Reading and Post-Reading Strategies. Procedia - Social and Behavioral Sciences , 46 , 4301-4305. https://doi.org/10.1016/j.sbspro.2012.06.244

Ampera, D., Tohir, M., \& Abidin, Z. (2018). Enhancing students ' mathematical problem posing skill through writing in performance tasks strategy Enhancing students ' mathematical problem posing skill through writing in performance tasks strategy.

Ası, D. Ş., Aydın, DG, \& Karabay, Ş. O. (2018). How preschool teachers handle problem situations : Discussing some indicators of emotional issues, $13,126-135$.

Bennett, J., Campbell, B., Braund, M., Harper, N., Holman, J., Ratcliffe, M., \& Robinson, A. (2004). Name of group and institutional location Contact details Authors And Review Team Review Group Membership Database management and administrative support, (May).

Bietenbeck, J. (2014). Teaching practices and cognitive skills is . Labour Economics . https://doi.org/10.1016/j.labeco.2014.03.002

Burke, A. (2011). Group work: How to use groups effectively. The Journal of Effective Teaching , 11 (2), 8795.

Dilekli, Y., \& Tezci, E. (2016). The relationship among teachers' classroom practices for teaching thinking skills, teachers' self-efficacy towards teaching thinking skills and teachers' teaching styles. Thinking Skills and Creativity , 21, 144-151. https://doi.org/10.1016/j.tsc.2016.06.001

Donovan, K., \& Herrington, C. (2018). Review of Economic Dynamics Factors affecting college attainment and student ability in the. Review of Economic Dynamics , 1 (2014), 1-21. https://doi.org/10.1016/j.red.2018.07.003

Forster, P., \& Quarcoo, R. (2018). Teacher competency in pattern-drafting lessons in senior high schools, $11,9-17$.

Groccia, JE (2018). What Is Student Engagement?, (154), 11-20. https://doi.org/10.1002/tl.20287

Hofmeyer, A., Toffoli, L., Vernon, R., Taylor, R., Klopper, HC, Knobloch, S., \& Fontaine, D. (2017). and teaching environment. Collegian, 6-11. https://doi.org/10.1016/j.colegn.2017.08.001 
Horng, J., Hsu, H., \& Tsai, C. (2019). Leisure , Sport \& Tourism Education Learning corporate ethics and social responsibility : Developing an in $\mathrm{fl}$ uential curriculum for undergraduate tourism and hospitality students. Journal of Hospitality, Leisure, Sport E Tourism Education , 24 (May 2018), 100109. https://doi.org/10.1016/j.jhlste.2019.01.003

Hotaman, D. (2010). The teaching profession: Knowledge of subject matter, teaching skills and personality traits. Procedia - Social and Behavioral Sciences , 2 (2), 1416-1420. https://doi.org/10.1016/j.sbspro.2010.03.211

Isa, A. (2010). Keefektifan pembelajaran berbantuan multimedia menggunakan metode inkuiri terbimbing untuk meningkatkan minat dan pemahaman siswa, 6, 58-62.

Kennedy, MJ, Hirsch, SE, Rodgers, WJ, Bruce, A., \& Lloyd, JW (2017). Supporting high school teachers' implementation of evidence-based classroom management practices. Teaching and Teacher Education , 63 , 47-57. https://doi.org/10.1016/j.tate.2016.12.009

Lai, NK, Ang, TF, Por, LY, \& Liew, CS (2018). Learning through intuitive interface: A case study on preschool learning. Computers and Education , 126 , 443-458. https://doi.org/10.1016/j.compedu.2018.08.015

Lee, MY, \& Cross Francis, D. (2018). Investigating the relationships among elementary teachers' perceptions of the use of students' thinking, their professional noticing skills, and their teaching practices. Journal of Mathematical Behavior , 51 (December 2016), 118-128. https://doi.org/10.1016/j.jmathb.2017.11.007

Lewis, EJ, Ludwig, PM, Nagel, J., \& Ames, A. (2019). Nurse Education Today Student ethical reasoning con fi dence pre / post an innovative makerspace course : A survey of ethical reasoning * Nurse Education Today , 75 (December 2018), 75-79. https://doi.org/10.1016/j.nedt.2019.01.011

Neghavati, A. (2016). Core Skills Training in a Teacher Training Programme. Procedia - Social and Behavioral Sciences , 232 (April), 617-622. https://doi.org/10.1080/00365540600978856

Ngang, TK, \& Sam, LC (2015). Principal Support in Lesson Study. Procedia - Social and Behavioral Sciences , 205 (May), 134-139. https://doi.org/10.1016/j.sbspro.2015.09.040

Ngang, TK, Yunus, HM, \& Hashim, NH (2015). Soft Skills Integration in Teaching Professional Training: Novice Teachers' Perspectives. Procedia - Social and Behavioral Sciences , 186 , 835-840. https://doi.org/10.1016/j.sbspro.2015.04.204

Sari, RT, \& Jusar, IR (2018). Analysis of Science Learning Process by Using Learning Module of Character Education Oriented through Quantum Learning Approach. Jurnal Penelitian Dan Pembelajaran IPA , 4 (1), 14. https://doi.org/10.30870/jppi.v4i1.2252

Shakibaei, Z., \& Golaiji, Y. (2012). The Effect of Mevlana's Masnavi Manavi Narratives on the Extent of Adolescent's Philosophizing Questioning Skills. Procedia - Social and Behavioral Sciences , 46 , 28822885. https://doi.org/10.1016/j.sbspro.2012.05.582

Stillman, SB, Stillman, P., Martinez, L., Freedman, J., Jensen, AL, \& Leet, C. (2017). Journal of Applied Developmental Psychology Strengthening social emotional learning with student, teacher, and schoolwide assessments is . Journal of Applied Developmental Psychology, (September 2016), 0-1. https://doi.org/10.1016/j.appdev.2017.07.010

Stocker, TC (2014). HOW TO ORGANIZE EFFECTIVE AND EFFICIENT GROUP WORK, 9 .

van Lankveld, T., Schoonenboom, J., Croiset, G., Volman, M., \& Beishuizen, J. (2017). The role of teaching courses and teacher communities in strengthening the identity and agency of teachers at university medical centres. Teaching and Teacher Education, 67, 399-409. https://doi.org/10.1016/j.tate.2017.07.011

Waes, S. Van, Maeyer, S. De, Moolenaar, NM, \& Petegem, P. Van. (2017). Strengthening networks : A social network intervention among higher education teachers. Learning and Instruction . https://doi.org/10.1016/j.learninstruc.2017.07.005

Ways, W. (2013). Handbook on Restructuring and Substantial School Improvement, (974), 2003-2005. 
Wighus, M., \& Bjørk, IT (2018). An educational intervention to enhance clinical skills learning: Experiences of nursing students and teachers. Nurse Education in Practice . https://doi.org/10.1016/j.nepr.2018.01.004

Yacek, D. (2018). Thinking Controversially : The Psychological Condition for Teaching, 00 (0).

Yang, Y., \& Wang, X. (2019). Modeling the intention to use machine translation for student translators: An extension of Technology Acceptance Model. Computers $\mathcal{E}$ Education. https://doi.org/10.1016/j.compedu.2019.01.015

Zheng, B., Yim, S., \& Warschauer, M. (2017). Social Media in the Writing Classroom and Beyond. The TESOL Encyclopedia of English Language Teaching , 1-5. https://doi.org/10.1002/9781118784235.eelt0555 